\title{
Mountain Landscape Preferences of Millennials Based on Social Media Data: A Case Study on Western Sichuan
}

\author{
Keying Ding ${ }^{1}$, Mian Yang ${ }^{1, * \mathbb{C}}$ and Shixian Luo ${ }^{2}$ \\ 1 Art College, Sichuan Tourism University, Chengdu 610100, China; keyingding@126.com \\ 2 Graduate School of Horticulture, Chiba University, Chiba 263-8522, Japan; 19hd4106@student.gs.chiba-u.jp \\ * Correspondence: yangmiansctu@126.com; Tel.: +86-138-8028-3481
}

Citation: Ding, K.; Yang, M.; Luo, S. Mountain Landscape Preferences of Millennials Based on Social Media Data: A Case Study on Western Sichuan. Land 2021, 10, 1246. https:// doi.org/10.3390/land10111246

Academic Editors: Cecilia Arnaiz Schmitz, Nicolas Marine and María Fe Schmitz

Received: 18 October 2021

Accepted: 11 November 2021

Published: 13 November 2021

Publisher's Note: MDPI stays neutral with regard to jurisdictional claims in published maps and institutional affiliations.

Copyright: (c) 2021 by the authors. Licensee MDPI, Basel, Switzerland. This article is an open access article distributed under the terms and conditions of the Creative Commons Attribution (CC BY) license (https:/ / creativecommons.org/licenses/by/ $4.0 /)$.

\begin{abstract}
Mountain area is one of the most important modern tourist attractions, and unique mountain landscapes are highly appealing to millennials. Millennials post their travel photos and comments on social media, and these media messages can positively influence other millennials' travel motivations. To fully understand the attraction of mountain tourist destinations to millennials, this study analyzed their landscape preferences using images posted on social media. As a case study, we analyzed the landscape resources in Western Sichuan Plateau Mountain Areas (WSPMA). We found that differences in genders, modes of transportation, and travel patterns of the millennials influenced their preferences for mountain landscapes. Our results broaden the current knowledge on mountain tourism from the perspective of millennials through social media data. Moreover, studying the landscape resources in WSPMA can facilitate the analysis of regional advantages. This will ultimately enhance tourism publicity and integrate various resources for tourism management and planning in more targeted and attractive ways.
\end{abstract}

Keywords: Western Sichuan Plateau Mountain Areas; millennials; mountain tourism; social media data; landscape preference

\section{Introduction}

Mountain tourism is developing at an unprecedented rate, thereby, turning to an important branch of contemporary tourism. Thus, mountain tourism nowadays plays an important role in the global tourism landscape, as it overlaps with people's desire to be close to nature and pursue health [1,2]. Mountain areas exhibit a certain degree of fragility due to their biodiversity factors and environmental/natural resource sensitivity [3]. Mountainous regions have been inhabited by aborigines for a long time, constituting a rich folklore and unique human landscape in such regions. All these characteristics make any economic activity, including tourism, which draws attention to the cultural and natural environment [4], result in the sustainable development of mountain areas being very important [5].

Tourism in mountain areas, after a long period of economic success and deep environmental transformation [6], has to be rediscovered [7]. The motivation stems from the importance of the attractiveness of tourism resources to tourists and plays a key role in tourism sustainability [8]. Also, the landscape richness is a determining factor for the development of mountain tourism [9]. From the tourism perspective, many studies have focused on the identity-related motivations in niche markets, such as backpacker tourism [10], museum visits [11], and lifestyle travelling [12]. However, further empirical research is needed to explore how identity-related motivations affect broader tourism decisions and outcomes [13]. We argue that research on landscape preferences in mountain tourism has important implications in mountain tourism development.

Millennials, defined as those born between the 1980s and 1995 [14], represent a very large proportion of the population with high purchasing power compared with the other 
age groups [15]. Most importantly, they represent the most important generation in the global economy, especially in tourism $[16,17]$. Consequently, there is a growing interest in the role of millennials in mountain tourism [18]. Mountain tourism sustainability is determined to some extent by the behavior of tourists [19], thus, studying the mountain tourism behavior of millennials can contribute to achieving sustainable development.

Cavagnaro et al. reported that millennials demonstrate interest in themes such as natural resources and prefer destinations with significant natural resources [20-25]. Giachino et al. [7] found seasonal differences in the millennials' choice of nature tourism destinations. Tieskens et al. [26,27] demonstrated that analytical studies on elements of mountain cultural landscapes are of high research value in exploring tourists' preferences for mountain landscapes. Several studies have also shown that millennials show great interest in sustainability issues in mountain tourism, and their participation is considered a necessary prerequisite for the sustainability and improvement of nature tourism [28]. Meanwhile, millennials themselves exhibit an important influence on environmental sustainability [29-31]. In particular, Sharmin et al. [32] verified how millennial tourists' awareness of environmental sustainability influences their environmentally sustainable activities when they visit nature reserves. Thus, state-of-the-art of nature tourism indicates that the preference for natural and cultural landscapes in mountainous areas is a small but important determinant of millennials' travel motivation and landscape perception. It further affects their travel behavior, and in turn affects mountain tourism sustainability. Due to this, research on millennials' natural and cultural landscape preferences in tourist destinations is significant for promoting the sustainable development of tourist destinations. In particular, tourists preferred activities vary with age [33], gender [34], mode of transportation [35], and travel patterns [36]. However, the differences in natural and cultural landscape preferences for mountain tourism among millennials by gender, mode of travel, and trip structure is yet to be studied in detail. Thus, a study on the differences in millennials' preferences for mountain landscapes across different forms of tourism is highly desirable.

Millennials are the backbone of the population, and they extensively use online social platforms to express themselves [37]. For millennials, it is important to co-create experiences and to provide feedback on good or bad experiences during their trip [38]. Meanwhile, the information collected about millennials' travel is also utilized to promote and to develop some destinations [39]. Loda et al. [40] highlighted the importance of millennials expressing their opinions by posting reviews and photos online in promoting destinations. In addition, the potential and impact of the content they share (e.g., photos and comments) cannot be neglected. Indeed, it is important to analyze the travel behavior of millennials through social media data.

The rise of social media has opened promising prospects for landscape preference research. Platforms such as Flickr and Instagram allow users to upload photos of their environment and place them on digital maps to collectively provide a publicly available database of volunteered geographic information [41,42]. One of the main advantages of volunteered geographic information is characterized by its ability to provide insights into popular spatial choices and preferences without experimental or survey bias [43].

Social media provides a common source of publicly available user-generated data to gain insights into spatial choices and landscape preferences [27,44]. In this domain, Richards et al. [45-47] used the spatial location of photographs, combined with the actual content of the photographs, to ensure that only the relevant photographs were considered to retrieve the information about the users' landscape preferences. In the study of Hausmann et al. [48], the content of photos from social media was analyzed to understand visitors' preferences for nature-based experiences in protected areas. Furthermore, Tieskens et al. [26] analyzed the aesthetic preferences of cultural landscapes in the Dutch river landscape through social media. All these studies confirmed an intrinsic link between the content of photos posted on social media and landscape preferences at the level of natural or cultural landscapes. Although, the limited information obtained through photographs makes it difficult to conduct extensive study, it provides non-negligible 
research values. Using photos posted by tourists on social media, we can explore the landscape value of mountain tourism from a more subtle and specific research perspective, which provides more research references for landscape researchers and tourism managers. Therefore, we attempted to explore the landscape preferences of millennials in mountain tourism by using photos posted by tourists on social media in two dimensions: natural and human landscapes.

To sum up, mountain regions are important for tourism research. Thus, we can use social media data to understand the landscape preferences of millennials in mountain tourism. Such studies would be in line with the behavioral habits of millennials and will help scholars in studying the landscape. The produced knowledge will not only open new research directions, but will help the decision/policy-makers and tourist managers to improve the tourism attractiveness in a tailored way. This is important for promoting the sustainable development of mountain tourism. To this end, we used social media data, (1) to understand the landscape preferences of millennials in mountain tourism from both natural and human landscape perspectives; (2) to explore whether there are differences in landscape preferences in mountain tourism among millennials based on gender, transportation modes, and travel patterns; and (3) to provide reference suggestions for sustainable tourism development and planning in mountain areas for the development and utilization of landscape resources.

\section{Materials and Methods}

The use of big data to investigate human behavior, facilitates tourism destination planning and management especially in the field of tourism [49]. We chose Ctrip (https:// www.ctrip.com, accessed on 10 July 2021), Xiaohongshu (https: / / www.xiaohongshu.com, accessed on 10 July 2021), and Mafengwo (https:/ / www.mafengwo.cn, accessed on 10 July 2021), which are the popular travel social networking sites in China. We decided to use tourism social media data to replace traditional research for the following reasons. First, social media data can alleviate the limitations associated with sample size, time, location, unresponsive bias, and self-reporting errors [50]. Second, the photos provided by users capture the local environment and experience, which are based on real life rather than on research reports [51]. Third, social media is an important medium for millennials to release and receive tourism information, whose research impact is of great significance and value [40]. Our study is based on the quantitative approach of content analysis of photos posted by tourists on social media. The content analysis is a numerical research method for objective, systematic, and quantitative analysis of literature content [52] and research on communication [53]. People upload photos on the internet that they like or are interested in, unless there are special instructions [33]. To this end, studying the specific landscape elements that attract tourists is required by encoding the photo content based on landscape characteristics, and by comparing the frequency of each element. Within this context, we also analyzed the correlation between landscape elements and preferences [26].

\subsection{Study Area}

The mountain area in Western China is vast, with salient characteristics such as complex ecosystem, lagging economic and social development, wide distribution of ethnic minorities, and obvious landscape diversity [54]. The area is rich in natural and cultural landscape resources, where the development conditions of mountain tourism are vastly superior and are of utmost importance and significance. The Western Sichuan Plateau Mountain Areas (WSPMA)are located in minority areas as a representative of the development of mountain tourism in Western China [2], where tourism is an essential development model for ethnic minority areas in Western Sichuan $[55,56]$. Due to this, we considered the WSPTA, as a typical mountain tourism research destination with multicultural and rich landscape resources, for our research study. 


\subsection{Data Collection}

Fashion or fame are the main factors affecting tourism destination selection [57,58]. In June 2021, we searched "Western Sichuan tourism destination" in the Ctrip.com (accessed on 10 July 2021) and selected the top 10 most popular tourism destinations as the specific object for this study. They include world natural heritage sites, national scenic spots, and $4 \mathrm{~A}$ or above representative tourism destinations (Figure 1). We also searched for photos posted by users during their travel in the 10 tourism destinations which we chose through Ctrip (https:/ / www.ctrip.com, accessed on 16 July 2021), Xiaohongshu (https:/ / www. xiaohongshu.com, accessed on 16 July 2021), and Mafengwo (https:/ /www.mafengwo.cn/, accessed on 16 July 2021). The analysis of shared travel photos was applied to understand the relevant outdoor recreational activities and preferences $[33,42,47]$. The principles for filtering data are explained here in detail. First, comments posted by visitors without any commercial behavior, were adopted to express the discriminatory criteria of their own feelings and sentiments. Then, users were required to complete the information. As mentioned, tourists' travel preferences were affected by age [33], gender [34], mode of transportation [35], travel pattern [36], and landscape preferences [42,47]. Therefore, we also collected information on the age, motivation for travel, and gender of our sample. Note that a sample must have a relatively in-depth process description and positive emotional expression of tourist behavior. Finally, the comments with salient advertising messages and copy marks were eliminated. The sample period was June 2020 to June 2021. After screening, 1230 users ( 450 male and 780 female) posting content were identified as the study sample, with 10,399 photos. Further, we explored millennials' landscape preferences for tourism in the WSPMA through image analysis.

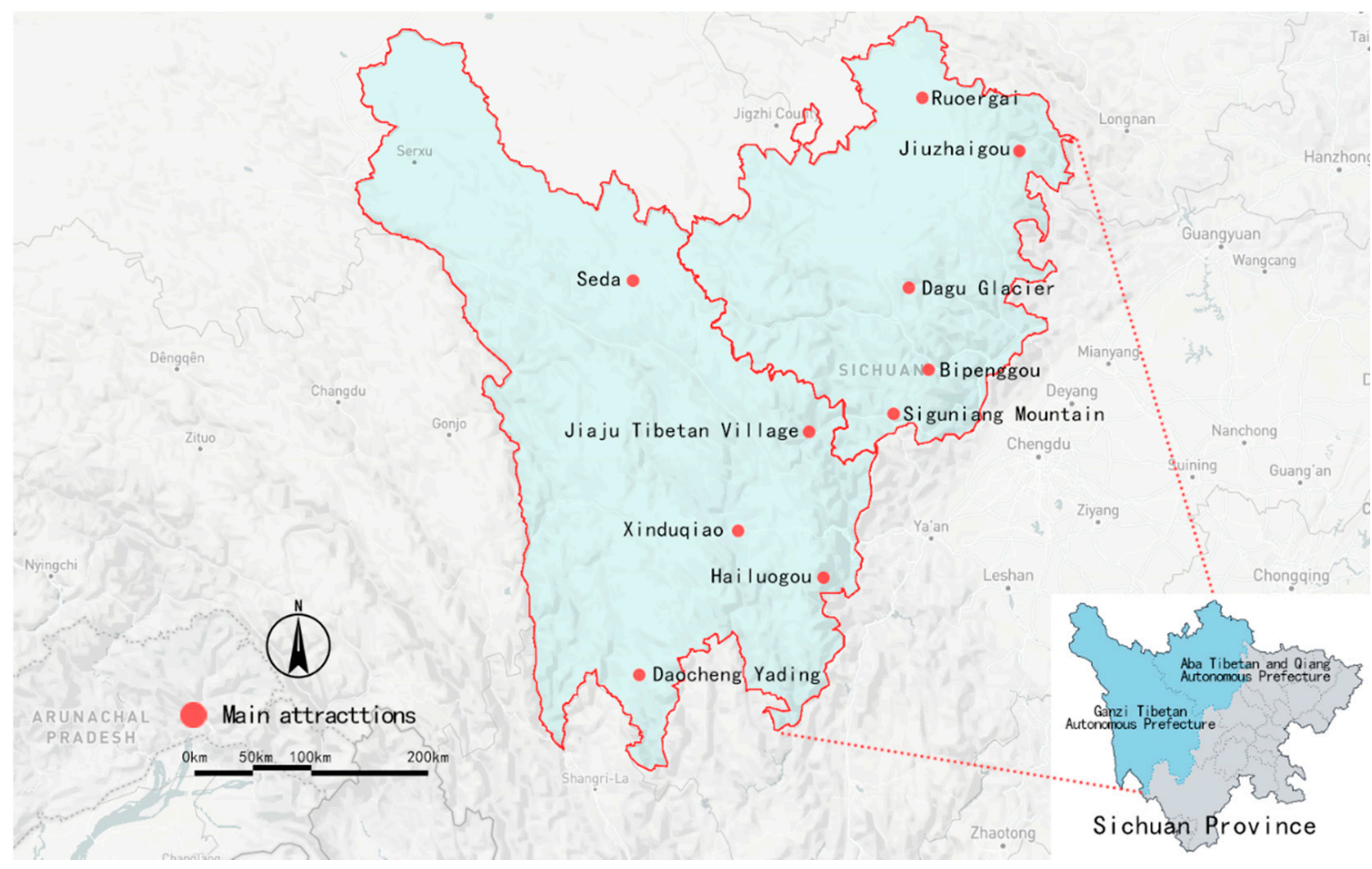

Figure 1. Study attraction locations.

\subsection{Data Statistics}

We identified the demographic characteristics of picture users by recording keywords in social media comments, and summarized these types of user information: gender (male and female), mode of transportation (self-driving, cycling, group following, and public transportation), and travel patterns (individuals, friends, families, and couples). 
We applied the classification method based on the main themes in the picture [45], and combined China's national standard for classification, investigation, and evaluation of tourism resources (GB/t18972-2003) (https:/ / www.mct.gov.cn/, accessed on 25 July 2021). In particular, Cao [59], and Shi [60] classified resources in the natural and cultural landscape, based on ethnic ecological areas and 11 subcategories: forest, waterscape, ice and snow, bare land, meadow, weather, heritage, customs and festivals, architecture, folk culture, and gastronomy (Table 1). Moreover, we quantified the number of pictures that belonged to multiple categories and calculated the frequency of landscape elements in each category (Table 2).

Table 1. Profile of landscape resource classification.

\begin{tabular}{|c|c|c|}
\hline Main Category & Subcategory & Landscape Unit \\
\hline \multirow{6}{*}{ Natural landscape } & Forest & Alpine forest, Low mountain forest, Virgin forest, Slow slope forest \\
\hline & Waterscape & Lake, River \\
\hline & Ice and snow & Snow mountain, Snow covered land \\
\hline & Bare land & River beach stone land, Alpine region \\
\hline & Meadow & $\begin{array}{l}\text { Sloping fields meadow, Lowland meadow, Pasture meadow, Wild } \\
\text { grassland, Lowland meadow }\end{array}$ \\
\hline & Weather & Sunrise, Sunset, Seas of clouds \\
\hline \multirow{5}{*}{ Human landscape } & Heritage & Building heritage \\
\hline & Customs and Festivals & Ethnic customs, Ethnic art, Celebrations, Clothing \\
\hline & Architecture & Residential building, Temple, Villages and towns, Diaolou structure \\
\hline & Folk culture & Folk belief, Religious belief \\
\hline & Gastronomy & Food, Gastronomy esthetic, Dining environment \\
\hline
\end{tabular}

Table 2. Profile of landscape types frequency.

\begin{tabular}{cccc}
\hline Item & $\mathbf{N}$ & Total & Mean \\
\hline natural landscape & 1230 & 18,328 & 14.9 \\
human landscape & 1230 & 3039 & 2.47 \\
forest & 1230 & 3748 & 3.05 \\
waterscape & 1230 & 3104 & 2.52 \\
ice and snow & 1230 & 4359 & 3.54 \\
bare land & 1230 & 2869 & 2.33 \\
meadow & 1230 & 1898 & 1.54 \\
weather & 1230 & 2350 & 1.91 \\
heritage & 1230 & 475 & 0.39 \\
customs and festivals & 1230 & 480 & 0.39 \\
architecture & 1230 & 1670 & 1.36 \\
folk culture & 1230 & 255 & 0.21 \\
gastronomy & 1230 & 159 & 0.13 \\
\hline
\end{tabular}

The data were analyzed using the IBM-SPSS 25 program. The results of the descriptive analysis were interpreted via the Kruskal-Wallis rank sum test by calculating samples, percentages, and frequencies based on the coding content described above. To further investigate the variability based on gender, mode of transportation, and travel patterns across the landscape types among millennials, we utilized Bonferroni adjustment for posthoc multiple testing of non-parametric tests of consumer behavior. The confidence intervals were set at $95 \%$, and differences in the associations were considered statistically significant at $p<0.05$ level. 


\section{Result}

\subsection{Statistical Characteristics of Millennial Tourists}

The sample of 1230 respondents consisted of 450 men (36.6\%) and 780 women (63.4\%). This proportion is consistent with the previous findings from Kimbrough [61] as women are keener to share on social media. From the mode of transportation perspective, 767 $(62.4 \%)$ self-driving tourists accounted for a much larger proportion of trips than the 25 $(2 \%)$ cycling tourists, $270(22 \%)$ group tourists, and $168(13.7 \%)$ public transport-using tourists combined. We suggest that the reason why most people opt self-drive rather than cycling is likely related to the high-altitude mountain environment of the WSPMA and the fact that most of the beautiful scenery can be enjoyed while on the road. Moreover, from the travel pattern standpoint, nearly $80 \%$ of tourists decide to travel in a group and only $20 \%$ travel alone. The relevant characteristics of participants are listed in Table 3.

Table 3. Basic information types of the samples.

\begin{tabular}{cccc}
\hline Types & Item & N & Percentage (\%) \\
\hline \multirow{2}{*}{ Gender } & Male & 450 & 36.6 \\
& Female & 780 & 63.4 \\
\hline \multirow{3}{*}{ Transportation } & Self-driving & 767 & 62.4 \\
& Cycling & 25 & 2 \\
& Travel agency & 270 & 22 \\
& Public transportation & 168 & 13.7 \\
\hline \multirow{3}{*}{ Travel pattern } & Individual & 288 & 23.4 \\
& With friends & 632 & 51.4 \\
& With family members & 143 & 11.6 \\
& Couples & 167 & 13.6 \\
\hline
\end{tabular}

\subsection{Photo Statistics}

Photos are visual elements captured by a photographer at a particular time, showing various landscape units. According to the landscape classification proposed in Table 1, we coded and analyzed the landscape characteristics of each collected photo (see Figures 2 and 3). According to the total number of landscape types in the photo, we regarded this as the landscape preference of tourists [33].

\subsection{Analysis of Millennials' Landscape Preferences}

At this stage of the analysis, we evaluated the differences in the aesthetics of various landscape types based on gender, mode of transportation, and travel pattern of the millennials. Table 2 shows a collation of photos posted by millennials on trips to the WSPMA. It reveals that natural landscape (14.9) appeared, on average, six times as often as human landscape (2.47). Among the landscape subcategories, ice and snow (3.54) > forest (3.05) > waterscape (2.52) $>$ bare land (2.33) $>$ weather $(1.91)>$ meadow (1.54) $>$ architecture (1.36) $>$ heritage (0.39), customs and festivals $(0.39)>$ folk culture (0.21), gastronomy (0.13). All landscape elements in the main category of natural landscapes appeared very frequently in the photographs. The highest frequency was identified for the snow and ice landscapes. For millennials, the appearance of meadows was the least frequent among all the natural landscapes. The main category of human landscape in the photos is less frequent than in the former, but the millennials also demonstrated an interest in architecture.

In terms of the millennials' gender differences in landscape preferences, Table 4 displays significant differences for waterscape $(p<0.001)$, weather $(p<0.001)$, heritage $(p<0.001)$, and customs and festivals $(p=0.041)$. Further, Figure 4 shows that males have a higher landscape preference for weather (665.99) and heritage (639.89), while females have higher landscape preference for waterscape (658.06) and customs and festivals (626.51). More multiple comparisons and results of gender details refer to Tables A1 and A2. 


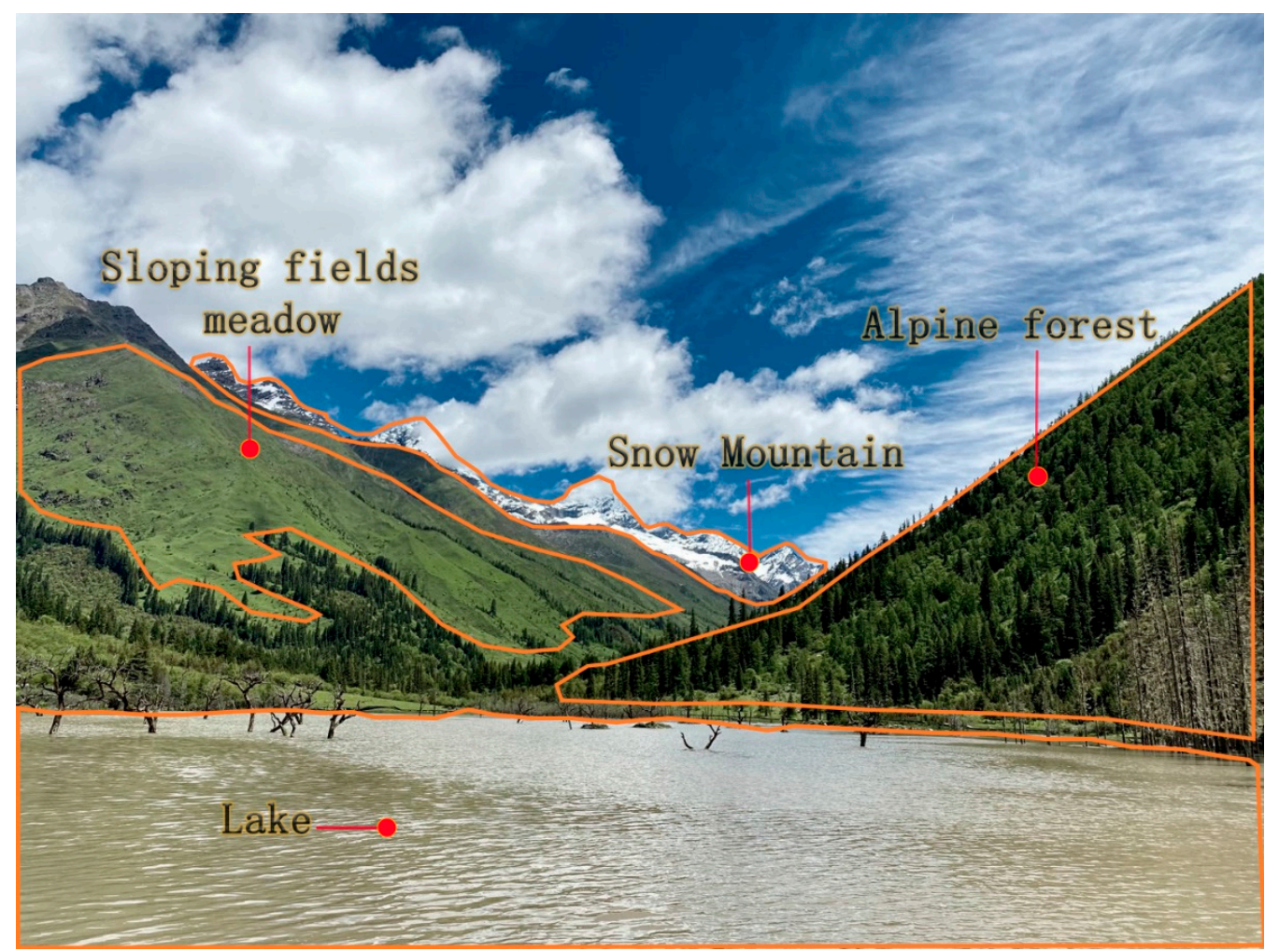

Figure 2. Landscape classification methods.

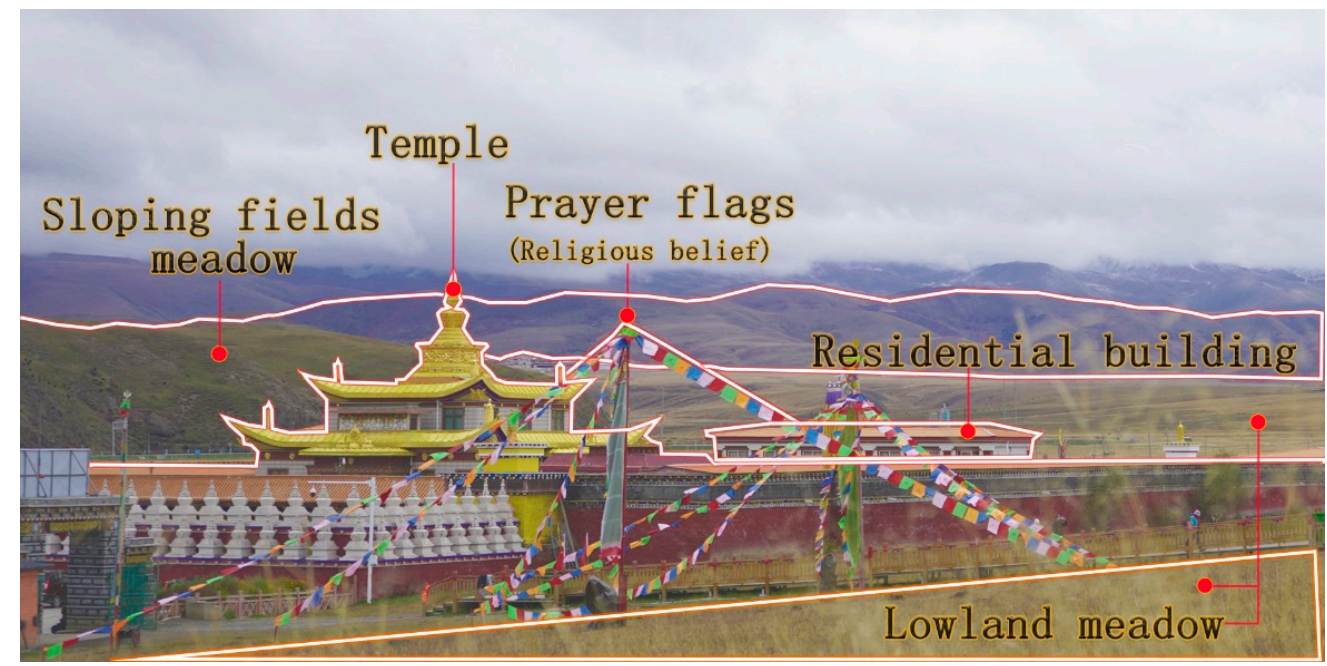

Figure 3. Landscape classification methods.

Table 4. Overall landscape preference difference.

\begin{tabular}{|c|c|c|c|c|c|c|c|c|c|c|c|c|c|}
\hline Variable & NL & HL & F & W & IS & BL & $\mathbf{M}$ & Wt & $\mathbf{H}$ & CF & A & FC & G \\
\hline Gender & 0.002 & 0.803 & 0.708 & 31.992 & 0.385 & 1.708 & 0.336 & 15.289 & 8.358 & 4.181 & 0.409 & 0.505 & 1.645 \\
\hline Transportation & 3.768 & 6.275 & 4.050 & 30.09 & 18.188 & 4.394 & 93.808 & 3.749 & 13.813 & 24.736 & 5.823 & 26.704 & 8.992 \\
\hline Travel pattern & 8.736 & 27.933 & 7.977 & 8.583 & 18.734 & 4.704 & 77.800 & 7.233 & 27.675 & 25.997 & 26.262 & 12.195 & 9.766 \\
\hline
\end{tabular}

Note: NL, natural landscape; HL, human landscape; F, forest; W, waterscape; IS, ice and snow; BL, bare land; M, meadow; WT, weather; H, heritage; $\mathrm{CF}$, customs and festivals; $\mathrm{A}$, architecture; FC, folk culture; $\mathrm{G}$, gastronomy. The figures are the chi-square values, and the bold ones represent significant differences $(p<0.05)$. 


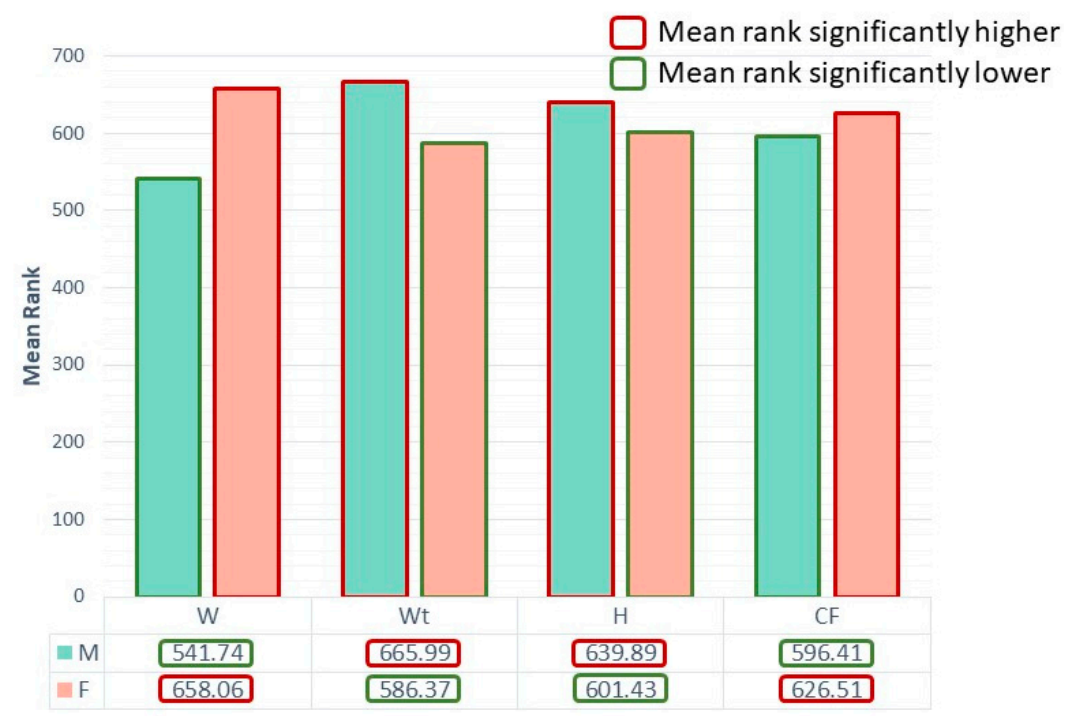

Figure 4. Kruskal-Wallis one-way ANOVA independent sample multiple comparisons of gender. Note: W: waterscape; WT: weather; H: heritage; CF: customs and festivals; A: architecture; FC: folk culture; G: gastronomy; M: male; F: female.

Differences in millennials' landscape preferences for different modes of transportation are shown in Table 4 . As seen, the millennials have pronounced landscape preferences for waterscape $(p<0.001)$, ice and snow $(p<0.001)$, meadow $(p<0.001)$, and heritage $(p=0.003)$, customs and festivals $(p<0.001)$, and folk culture $(p<0.001)$. As also seen from Figure 5, millennials traveling with travel agencies exhibit higher preference for waterscape (693.58), compared with the other groups, and also exhibited higher preference for ice and snow landscape (674.11) and gastronomy (636.27) than the self-driving groups $(\mathrm{IS}=588.19, \mathrm{G}=606.98)$. However, there was lower preference for customs and festivals (559.19) than the other groups. In addition, self-driving millennials disclosed a higher landscape preference for meadows (681.49), compared with the other groups, while the millennials that travelled by public transportation exhibited a higher landscape preference for heritage sites (665.66) than the other groups. For millennials, significant preference differences were also found between multi-landscape preferences and different modes of transportation. More multiple comparisons and results of mode of transportation details refer to Tables A1 and A2.

Differences in millennials' landscape preference were based on different travel patterns. Table 4 shows the progressive significance value in the natural landscape $(p=0.033)$, human landscape $(p<0.001)$, ice and snow $(p<0.001)$, meadow $(p<0.001)$, and heritage $(p<$ $0.001)$, customs and festivals $(p<0.001)$, architecture $(p<0.001)$, folk culture $(p=0.007)$, and gastronomy $(p=0.021)$, is less than 0.05 . From Figure 6 , we found that individual millennial tourists showed higher landscape preferences for customs and festivals (676.94), but lower landscape preference for meadows (488.41) than the other groups. Millennials travelling with friends had great landscape preferences for human landscapes in heritage sites (638.9), architecture sites (645.27), and gastronomy (625.19). Millennials travelling with family showed higher preference for natural landscapes (687.26) than individual ones (587.96), but lower preference for human landscapes (478.02) on multiple sides, especially in architectural landscapes (497.4). More multiple comparisons and results of travel pattern details refer to Tables A1 and A2. 


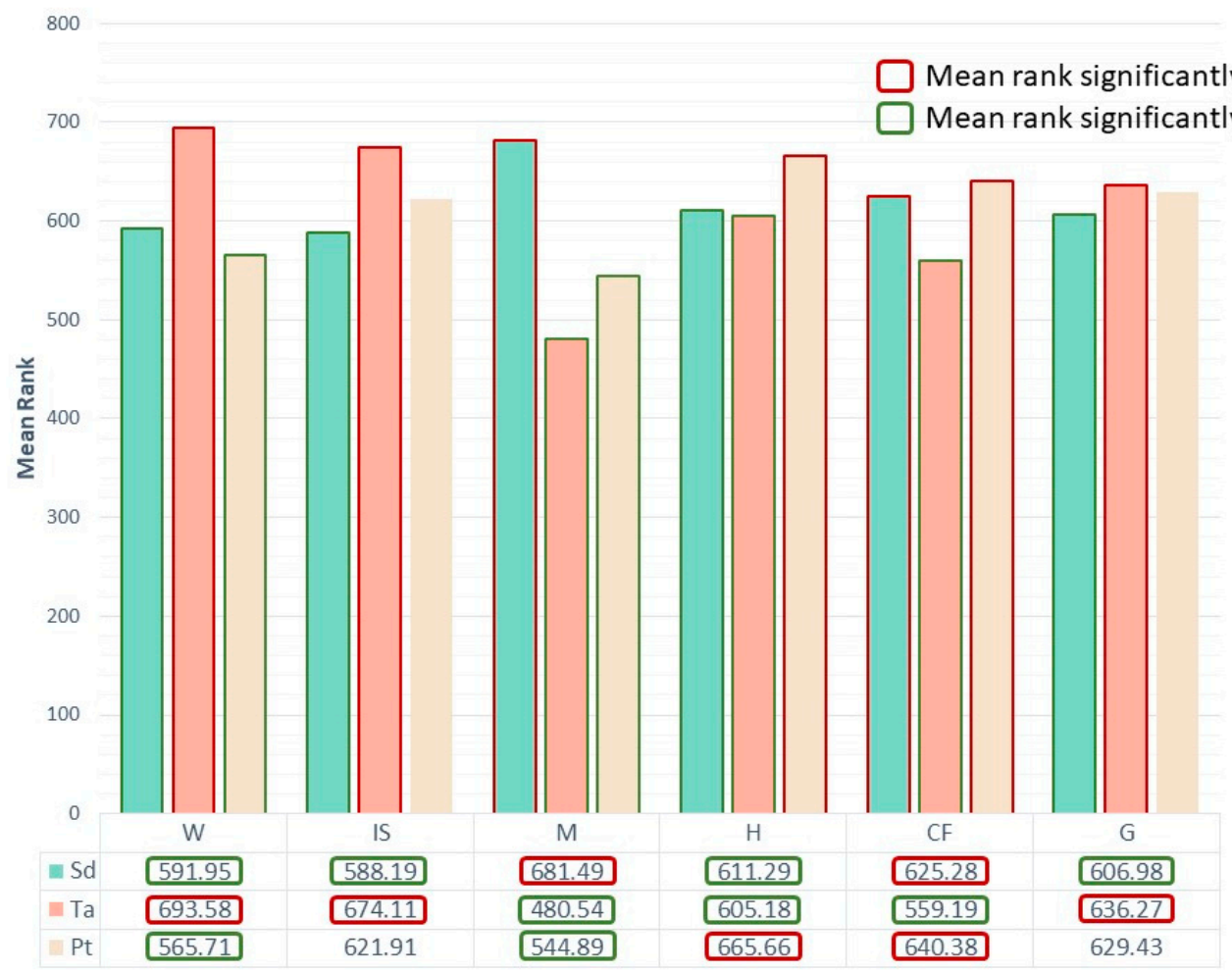

Figure 5. Kruskal-Wallis one-way ANOVA independent sample multiple comparison of mode of transportation. Note: W: waterscape; IS: ice and snow; M: meadow; H: heritage; CF: customs and festivals; G: gastronomy; Sd, Self-driving; Ta, Travel Agency; Pt, Public transportation.

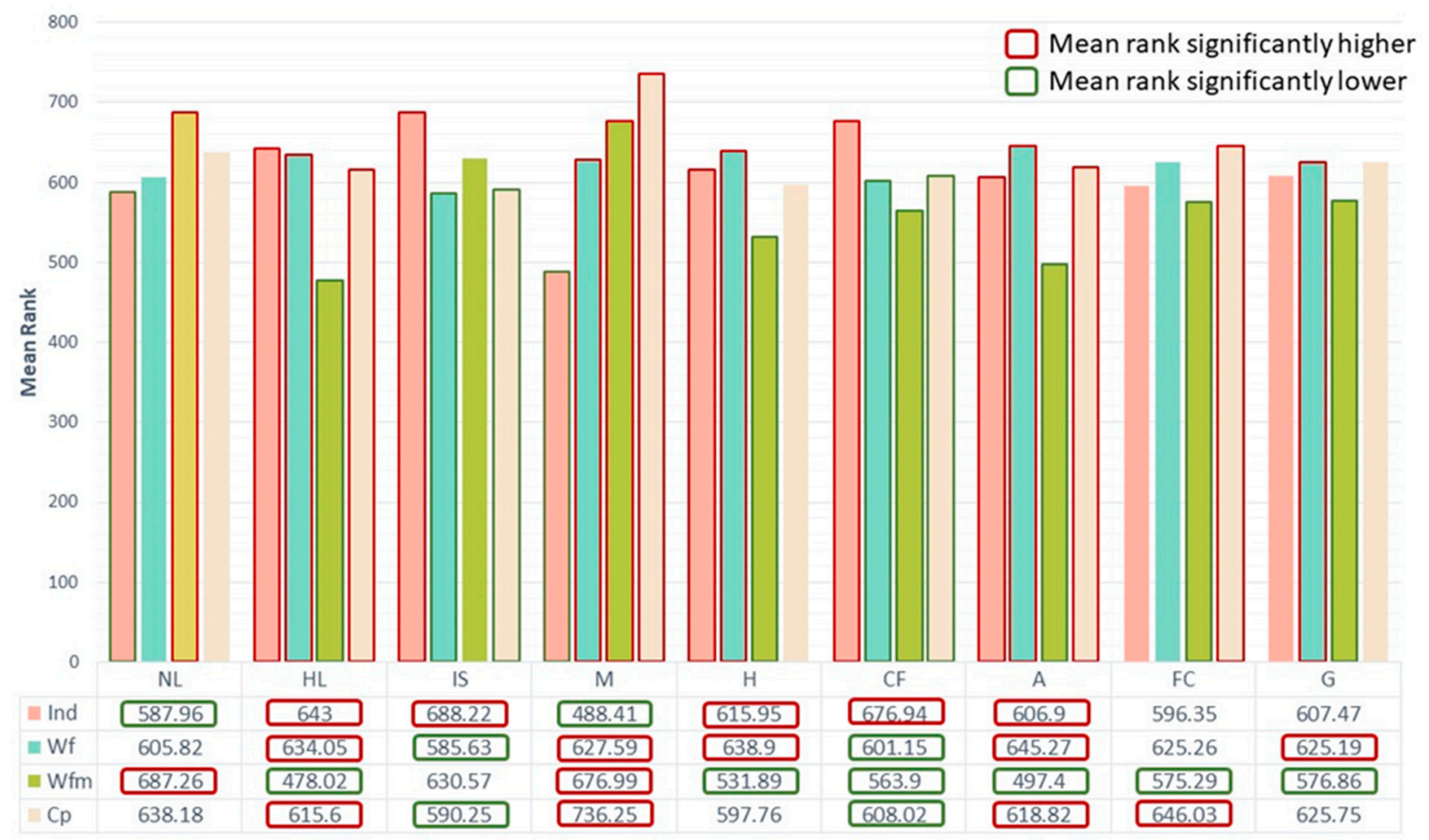

Figure 6. Kruskal-Wallis one-way ANOVA independent sample multiple comparison of travel pattern. Note: NL: natural landscape; HL: human landscape; IS: ice and snow; M: meadow; H: heritage; CF: customs and festivals; A: architecture; FC: folk culture; G: gastronomy; Ind: Individual; Wf: With friends; Wfm: With family members; Cp, Couples. 


\section{Discussion}

We selected the mountainous region of the WSPMA as the study area and examined the landscape preferences of millennials from the perspective of natural and human landscapes. This analysis was performed using social media data while considering the effects of different genders, modes of transportation, and travel patterns on tourist destination preference.

We found that, in contrast to the findings of Krueger et al. [62], self-driving travel is a prominent feature of mountain tourism among millennials. This may be on account of the plateau climate of WSPMA, and because most of the beautiful scenery is along the way, rather than in a tourist destination. Compared with public transportation, self-driving is more flexible in terms of time and travel freedom, thus, leading to better enjoyment of the unique landscape of the mountain area. We also found that architectural culture emerges most frequently in the human landscape, seemingly because the local architecture has a very strong and unique ethnic cultural style.

At the level of natural landscape, millennials demonstrated substantial interest in mountain forests, waterscape, ice and snow, and bare-land landscapes. Notably, their common denominator is the superiority and uniqueness of mountain natural landscapes. This indicates that natural factors are the primary drivers of the millennials' preferences for mountain destinations. This finding agrees with the findings of Higham's [20], who suggests that millennials show a high interest in natural landscapes. We also found that the millennials have different landscape preferences based on differences in genders, modes of transportation, and travel patterns for specific mountain landscape elements.

First, in terms of gender, both male and female groups expressed different landscape preferences. In particular, women have a higher aesthetic preference for waterscape than men, while men show a higher landscape preference for weather landscapes than women. Among the tourists with different modes of transportation, those travelling in a group cared more about the natural scenery of the mountainous areas of the WSPMA, especially waterscape and ice and snow landscape. In contrast, tourists travelling by car preferred meadow landscapes. Moreover, individual tourists were more inclined to visit ice and snow landscapes compared with the tourists using other modes of travel. There was a striking contrast in the preference results for meadow landscapes as family tourists clearly exhibited a higher preference for natural landscapes than individual tourists.

Likewise, with respect to human landscape, this study identified some prominent differences. In terms of gender, females expressed a higher preference for customs and festivals landscapes than males, while males showed a significantly higher preference for heritage landscapes. In terms of different modes of transportation, self-driving visitors showed more preference for customs and festivals, and folk culture; public transport visitors showed more preference for heritage, customs and festivals. This indicates that self-driving and public transport visitors are the main visitors among millennials who are interested in human landscapes. We did not expect a higher preference for food tourism among visitors travelling in a group, which is different from the commonly observed pattern with group tours. In terms of different travel patterns, individual tourists expressed a clear preference for heritage, architecture, customs and festivals, especially, customs and festivals. Compared with the preferences for natural landscapes, individual tourists were one of the main clienteles for human landscapes. More specifically, couples preferred folk culture landscapes. In such landscapes, many photos of the couples were captured using local ethnic elements. It should also be noted that family tourists expressed notably less interest in human landscapes than the other three categories of visitors.

The combination of the landscape preference results for natural and human landscapes likely unravels in the following pattern. Family trips and group self-driving trips prefer landscapes where they can relax, talk, and indulge in outdoor activities. This drives their preferential choice toward meadow landscapes. Family trips take into account the older and the younger members of the family, who enjoy more bonding time and relaxation in a natural environment, thus influencing the preference of this group for architectural 
and other cultural landscapes. The collation of photographs showed that millennial girls prefer landscapes where people photography can be taken, while boys prefer ornamental landscapes, in line with the gender preference results. Those who travel individually are more attracted to the human landscapes of ethnic minorities in the WSPMA, arousing their desire to explore history, folklore, and ethnic culture.

\section{Conclusions}

There are three main contributions of this study.

First, our findings broaden the current research results related to mountain tourism [1]. We innovatively studied the natural and human landscape preferences of millennials for mountain tourism based on social media data. The research results showed that the geographic content determined from social media can be used as a reliable substitute for traditional survey methods and used to explore tourists' landscape preferences in mountain tourism. In future research, the drivers behind these preferences and the strengths and weaknesses of each landscape element can also be investigated. This will ultimately improve the competitiveness of mountain tourism from a detailed perspective.

Second, these findings improve the understanding of tourists' preferences for landscapes and reveal useful tourism management implications. In particular, decision/policymakers and tourism managers need to understand the landscape preferences of tourists [48], the specific subdivision of landscape elements and tourist demographic characteristics can help government and managers conduct more targeted tourism management, planning, and promotion. To our knowledge, the mountain tourism populations and landscape preferences have not been studied to an appropriate extent to date [7].

Third, our findings enrich the research related to social media in landscape preferences. Among the current studies on landscape preferences, landscape studies based on social media data have increasingly become a research hotspot. However, to the best of our knowledge, there are few studies on landscape preferences for mountain tourism through social media [63], so our study complements the research on social media in landscape preferences.

Based on the research of Tieskens et al. [26,27], our results confirm that millennials with different genders, modes of transportation, and travel patterns have their own preferences for mountain landscapes. These differences have important implications in the marketing management and design planning of scenic areas. These can help the government and tourism managers to analyze the advantages of local landscape resources and position products and services according to the aesthetic preferences of different groups for different landscapes. Thus, making tourism promotion and tourism planning more relevant and attractive.

Millennials' preference for natural landscapes can promote a sense of nature conservation, thereby, promoting sustainable behavior towards nature [39,40,49]. At the same time, landscape preferences affect tourism behavior and enhance place attachment, thus, strengthening the willingness to protect these natural areas. Decision/policy-makers and tourism managers should focus on the conservation of natural ecosystems when planning mountain tourism. While carrying out tourism promotion, the unique natural scenery of the WSPMA and nature conservation-related promotion should be performed through the various social media platforms commonly used by millennials. In terms of cultural landscapes, Xu's [64] study confirmed the preference of millennials for cultural landscapes. In response to the low preference for cultural landscapes among tourists on family trips, decision/policy-makers and tourism managers can enrich the form of ethnic activities, so that children and the elderly can be more involved in ethnic cultural activities and experience ethnic cultural features in an interesting way. Children and the elderly can learn about the diverse cultures of the WSPMA through the medium of information reception commonly used by children and the elderly, thus enhancing their interest in cultural landscapes.

On a more detailed level, scenic area operators can create different types of narration (viewpoints or storytelling lines) along the road according to the functional needs of the 
various visitors to the landscape. For instance, meadow landscapes can be established with space for relaxing, to create a better experience for visitors. In line with the results of Hargittai [65], we found that women are keener to share on social media, so landscape operators can target female groups and create spots that are suitable for photographing people. Tourism managers should use social media to promote high-quality local specialty restaurants to meet the demand for food from people that do not prefer group tours.

\section{Limitations}

This study had some limitations. First, the size of the samples and collection time were imperfect. Due to the incomplete demographic information from social media data, it was challenging to study education [66] and income [67]. Furthermore, some sample sizes were too small to be analyzed, namely, the transportation by cycling was excluded because its size was too small. Second, there is an inherent limitation in social media data. More specifically, compared with extensive surveys, this method cannot be used to evaluate the impact of social factors on shared content [68], although, social media data are authentic and objective [69].

These limitations do not impact the value of our findings as we strictly focused on the millennials and conducted relevant discussions and research based on their reliance on social media. Overall, our findings certainly contribute to the currently scanty knowledge about the millennial generation in the sustainable development of mountain tourism.

Author Contributions: Conceptualization, M.Y. and S.L.; methodology, M.Y., S.L. and K.D.; software, K.D.; validation, M.Y. and K.D.; formal analysis, M.Y.; investigation, K.D.; resources, M.Y.; data curation, M.Y. and K.D.; writing-original draft preparation, M.Y. and K.D.; writing-review and editing, M.Y. and S.L.; visualization, M.Y. and K.D.; supervision, M.Y.; project administration, M.Y.; funding acquisition, M.Y. All authors have read and agreed to the published version of the manuscript.

Funding: This research was funded by the Sichuan Provincial Social Science Key Research Base (Kangba Cultural Research Center) "Study on the Motivation of Humanistic Tourism along the Sichuan-Tibet Highway in Kang District", grant number: KBYJ2021B011; The Innovation Training Program for University Students of Sichuan Province "Study on the Millennials' Aesthetic Preferences of Mountain Tourism based on Social Media Data", grant number: S202111552126.

Institutional Review Board Statement: The study was conducted according to the guidelines of the Declaration of Helsinki, all the necessary information regarding the study was given. The photos we chose were publicly posted on social media platforms and the study did not expose the users to any harm. Therefore, this experiment was conducted with the approval of the Academic Committee of Sichuan Tourism University, but no submission for review was required.

Informed Consent Statement: Not applicable.

Data Availability Statement: The data presented in this study are available on request from the corresponding author. The data are not publicly available due to privacy.

Acknowledgments: We thank the Sichuan Provincial Social Science Key Research Base (Kangba Cultural Research Center), the Organizer of Innovation Training Program for University Students of Sichuan Province for funding and anonymous reviewers who provided invaluable advice on how to improve the manuscript.

Conflicts of Interest: The authors declare no conflict of interest. 


\section{Appendix A}

Table A1. Kruskal-Wallis one-way ANOVA independent sample multiple comparison.

\begin{tabular}{|c|c|c|c|c|c|c|c|c|c|}
\hline \multirow[t]{2}{*}{ Variable } & \multicolumn{3}{|c|}{ Gender } & \multicolumn{3}{|c|}{ Transportation } & \multicolumn{3}{|c|}{ Travel Pattern } \\
\hline & Item & $\begin{array}{c}\text { Mean } \\
\text { Rank }\end{array}$ & SE & Item & $\begin{array}{l}\text { Mean } \\
\text { Rank }\end{array}$ & SE & Item & $\begin{array}{l}\text { Mean } \\
\text { Rank }\end{array}$ & SE \\
\hline \multirow{4}{*}{ NL } & Male & 616.04 & 0.414 & $\mathrm{Sd}$ & 616.44 & 0.308 & Ind & 587.96 & 0.357 \\
\hline & Female & 615.19 & 0.255 & Cy & 688.96 & 0.842 & Wf & 605.82 & 0.326 \\
\hline & & & & $\mathrm{Ta}$ & 631.12 & 0.398 & Wfm & 687.26 & 0.705 \\
\hline & & & & $\mathrm{Pt}$ & 575.18 & 0.478 & $\mathrm{Cp}$ & 638.18 & 0.613 \\
\hline \multirow{4}{*}{ HL } & Male & 604.22 & 0.236 & $\mathrm{Sd}$ & 610.32 & 0.161 & Ind & 643.00 & 0.251 \\
\hline & Female & 622.01 & 0.135 & $\mathrm{Cy}$ & 618.22 & 0.233 & Wf & 634.05 & 0.182 \\
\hline & & & & $\mathrm{Ta}$ & 594.05 & 0.194 & Wfm & 478.02 & 0.143 \\
\hline & & & & $\mathrm{Pt}$ & 673.23 & 0.386 & $\mathrm{Cp}$ & 615.60 & 0.339 \\
\hline \multirow{4}{*}{$\mathrm{F}$} & Male & 626.57 & 0.137 & $\mathrm{Sd}$ & 600.22 & 0.103 & Ind & 596.10 & 0.125 \\
\hline & Female & 609.11 & 0.091 & $\mathrm{Cy}$ & 656.02 & 0.308 & Wf & 613.20 & 0.111 \\
\hline & & & & $\mathrm{Ta}$ & 644.75 & 0.150 & Wfm & 689.90 & 0.242 \\
\hline & & & & $\mathrm{Pt}$ & 632.21 & 0.182 & $\mathrm{Cp}$ & 593.98 & 0.217 \\
\hline \multirow{4}{*}{ W } & Male & 541.74 & 0.123 & $\mathrm{Sd}$ & 591.95 & 0.095 & Ind & 651.32 & 0.134 \\
\hline & Female & 658.06 & 0.093 & $\mathrm{Cy}$ & 829.38 & 0.349 & Wf & 605.52 & 0.107 \\
\hline & & & & $\mathrm{Ta}$ & 693.58 & 0.161 & Wfm & 648.14 & 0.252 \\
\hline & & & & $\mathrm{Pt}$ & 565.71 & 0.192 & $\mathrm{Cp}$ & 563.54 & 0.193 \\
\hline \multirow{4}{*}{ IS } & Male & 607.47 & 0.213 & $\mathrm{Sd}$ & 588.19 & 0.153 & Ind & 688.22 & 0.218 \\
\hline & Female & 620.13 & 0.141 & $\mathrm{Cy}$ & 777.30 & 0.533 & Wf & 585.63 & 0.172 \\
\hline & & & & $\mathrm{Ta}$ & 674.11 & 0.256 & Wfm & 630.57 & 0.342 \\
\hline & & & & $\mathrm{Pt}$ & 621.91 & 0.292 & $\mathrm{Cp}$ & 590.25 & 0.335 \\
\hline \multirow{4}{*}{$\mathrm{BL}$} & Male & 632.47 & 0.149 & $\mathrm{Sd}$ & 606.46 & 0.106 & Ind & 604.64 & 0.113 \\
\hline & Female & 605.71 & 0.087 & Cy & 741.50 & 0.340 & Wf & 613.32 & 0.119 \\
\hline & & & & $\mathrm{Ta}$ & 631.03 & 0.149 & Wfm & 671.68 & 0.247 \\
\hline & & & & $\mathrm{Pt}$ & 613.08 & 0.182 & $\mathrm{Cp}$ & 594.37 & 0.201 \\
\hline \multirow{4}{*}{ Md } & Male & 622.35 & 0.134 & $\mathrm{Sd}$ & 681.49 & 0.109 & Ind & 488.41 & 0.076 \\
\hline & Female & 611.55 & 0.090 & $\mathrm{Cy}$ & 523.16 & 0.154 & Wf & 627.59 & 0.107 \\
\hline & & & & $\mathrm{Ta}$ & 480.54 & 0.092 & $\mathrm{Wfm}$ & 676.99 & 0.277 \\
\hline & & & & $\mathrm{Pt}$ & 544.89 & 0.118 & $\mathrm{Cp}$ & 736.25 & 0.232 \\
\hline \multirow{4}{*}{$\mathrm{Wt}$} & Male & 665.99 & 0.107 & $\mathrm{Sd}$ & 615.56 & 0.099 & Ind & 659.52 & 0.184 \\
\hline & Female & 586.37 & 0.089 & Cy & 580.08 & 0.265 & Wf & 605.57 & 0.081 \\
\hline & & & & $\mathrm{Ta}$ & 593.27 & 0.100 & Wfm & 575.13 & 0.184 \\
\hline & & & & $\mathrm{Pt}$ & 656.24 & 0.163 & $\mathrm{Cp}$ & 611.74 & 0.201 \\
\hline \multirow{4}{*}{$\mathrm{H}$} & Male & 639.89 & 0.068 & $\mathrm{Sd}$ & 611.29 & 0.041 & Ind & 615.95 & 0.065 \\
\hline & Female & 601.43 & 0.030 & Cy & 519.00 & 0.000 & Wf & 638.90 & 0.046 \\
\hline & & & & $\mathrm{Ta}$ & 605.18 & 0.040 & Wfm & 531.89 & 0.024 \\
\hline & & & & $\mathrm{Pt}$ & 665.66 & 0.119 & $\mathrm{Cp}$ & 597.76 & 0.100 \\
\hline \multirow{4}{*}{$\mathrm{CF}$} & Male & 596.41 & 0.046 & $\mathrm{Sd}$ & 625.28 & 0.037 & Ind & 676.94 & 0.051 \\
\hline & Female & 626.51 & 0.032 & $\mathrm{Cy}$ & 756.34 & 0.187 & Wf & 601.15 & 0.040 \\
\hline & & & & $\mathrm{Ta}$ & 559.19 & 0.038 & Wfm & 563.90 & 0.053 \\
\hline & & & & $\mathrm{Pt}$ & 640.38 & 0.067 & $\mathrm{Cp}$ & 608.02 & 0.069 \\
\hline \multirow{4}{*}{ A } & Male & 623.02 & 0.126 & $\mathrm{Sd}$ & 610.51 & 0.090 & Ind & 606.90 & 0.152 \\
\hline & Female & 611.16 & 0.081 & Cy & 501.96 & 0.174 & Wf & 645.27 & 0.103 \\
\hline & & & & $\mathrm{Ta}$ & 617.21 & 0.122 & Wfm & 497.40 & 0.073 \\
\hline & & & & $\mathrm{Pt}$ & 652.45 & 0.218 & $\mathrm{Cp}$ & 618.82 & 0.174 \\
\hline
\end{tabular}


Table A1. Cont.

\begin{tabular}{|c|c|c|c|c|c|c|c|c|c|}
\hline \multirow[t]{2}{*}{ Variable } & \multicolumn{3}{|c|}{ Gender } & \multicolumn{3}{|c|}{ Transportation } & \multicolumn{3}{|c|}{ Travel Pattern } \\
\hline & Item & $\begin{array}{l}\text { Mean } \\
\text { Rank }\end{array}$ & SE & Item & $\begin{array}{l}\text { Mean } \\
\text { Rank }\end{array}$ & SE & Item & $\begin{array}{l}\text { Mean } \\
\text { Rank }\end{array}$ & SE \\
\hline \multirow{4}{*}{ FC } & Male & 621.18 & 0.029 & Sd & 637.96 & 0.023 & Ind & 596.35 & 0.029 \\
\hline & Female & 612.22 & 0.022 & Cy & 556.96 & 0.080 & Wf & 625.26 & 0.027 \\
\hline & & & & $\mathrm{Ta}$ & 563.95 & 0.035 & Wfm & 575.29 & 0.052 \\
\hline & & & & $\mathrm{Pt}$ & 604.54 & 0.045 & $\mathrm{Cp}$ & 646.03 & 0.040 \\
\hline \multirow{4}{*}{ G } & Male & 606.94 & 0.028 & $\mathrm{Sd}$ & 606.98 & 0.018 & Ind & 607.47 & 0.022 \\
\hline & Female & 620.44 & 0.016 & Cy & 559.00 & 0.000 & Wf & 625.19 & 0.024 \\
\hline & & & & $\mathrm{Ta}$ & 636.27 & 0.030 & Wfm & 576.86 & 0.025 \\
\hline & & & & $\mathrm{Pt}$ & 629.43 & 0.041 & $\mathrm{Cp}$ & 625.75 & 0.036 \\
\hline
\end{tabular}

Note: NL, natural landscape; HL, human landscape; F, forest; W, waterscape; IS, ice and snow; BL, bare land; $\mathrm{M}$, meadow; $\mathrm{WT}$, weather; $\mathrm{H}$, heritage; $\mathrm{CF}$, customs and festivals; $\mathrm{A}$, architecture; $\mathrm{FC}$, folk culture; G, gastronomy; Sd, Self-driving; Cy, Cycling; Ta, Travel agency; Pt, Public transportation; Ind, Individual; Wf, With friends; Wfm, With family members; $\mathrm{Cp}$, Couples.

Table A2. Multiple comparison results.

\begin{tabular}{|c|c|c|c|c|c|c|c|c|c|c|}
\hline Variable & $\begin{array}{c}\text { (I) } \\
\text { Group }\end{array}$ & $\begin{array}{c}(\mathrm{J}) \\
\text { Group }\end{array}$ & $\begin{array}{c}\text { Mean } \\
\text { Difference } \\
(\mathrm{I}-\mathrm{J})\end{array}$ & Std. Error & $\begin{array}{l}\text { Adjusted } \\
\text { Sig. }\end{array}$ & $\begin{array}{c}\text { (I) } \\
\text { Group }\end{array}$ & $\begin{array}{c}(\mathrm{J}) \\
\text { Group }\end{array}$ & $\begin{array}{c}\text { Mean } \\
\text { Difference } \\
(\mathrm{I}-\mathrm{J})\end{array}$ & Std. Error & $\begin{array}{l}\text { Adjusted } \\
\text { Sig. }\end{array}$ \\
\hline NL & & & & & & Ind & $\mathrm{Wfm}$ & -99.302 & 36.301 & 0.0037 \\
\hline \multirow[t]{3}{*}{$\mathrm{HL}$} & & & & & & Wfm & $\mathrm{Cp}$ & -137.577 & 38.187 & 0.002 \\
\hline & & & & & & Wfm & Wf & 156.024 & 31.037 & 0.000 \\
\hline & & & & & & Wfm & Ind & 164.974 & 34.287 & 0.000 \\
\hline \multirow[t]{2}{*}{ W } & $\mathrm{Pt}$ & $\mathrm{Ta}$ & 124.823 & 33.411 & 0.001 & & & & & \\
\hline & $\mathrm{Sd}$ & $\mathrm{Ta}$ & -98.870 & 24.060 & 0.000 & & & & & \\
\hline \multirow[t]{2}{*}{ IS } & Sd & $\mathrm{Ta}$ & -83.555 & 23.857 & 0.001 & Wf & Ind & 102.589 & 24.505 & 0.000 \\
\hline & & & & & & $\mathrm{Cp}$ & Ind & 97.964 & 33.525 & 0.021 \\
\hline \multirow[t]{4}{*}{ M } & Sd & $\mathrm{Ta}$ & -196.417 & 21.865 & 0.000 & Ind & Wf & -139.184 & 22.395 & 0.000 \\
\hline & $\mathrm{Pt}$ & Sd & 133.764 & 26.320 & 0.000 & Ind & Wfm & -188.580 & 32.225 & 0.000 \\
\hline & & & & & & Ind & $\mathrm{Cp}$ & -247.845 & 30.639 & 0.000 \\
\hline & & & & & & Wf & $\mathrm{Cp}$ & -108.661 & 27.408 & 0.000 \\
\hline \multirow[t]{2}{*}{$\mathrm{H}$} & $\mathrm{Ta}$ & $\mathrm{Pt}$ & -59.430 & 21.824 & 0.019 & Wfm & Ind & 84.062 & 22.994 & 0.002 \\
\hline & Sd & $\mathrm{Pt}$ & 53.325 & 18.919 & 0.014 & Wfm & Wf & 107.007 & 20.815 & 0.000 \\
\hline \multirow[t]{3}{*}{$\mathrm{CF}$} & $\mathrm{Ta}$ & $\mathrm{Sd}$ & 64.642 & 17.072 & 0.000 & Wfm & Ind & 113.042 & 25.438 & 0.000 \\
\hline & $\mathrm{Ta}$ & $\mathrm{Pt}$ & -79.594 & 23.707 & 0.002 & Wf & Ind & 75.793 & 17.679 & 0.000 \\
\hline & & & & & & $\mathrm{Cp}$ & Ind & 68.926 & 24.186 & 0.026 \\
\hline \multirow[t]{3}{*}{ A } & & & & & & Wfm & Ind & 109.495 & 32.049 & 0.004 \\
\hline & & & & & & $\mathrm{Wfm}$ & $\mathrm{Cp}$ & -121.415 & 35.694 & 0.004 \\
\hline & & & & & & $\mathrm{Wfm}$ & $W f$ & 147.863 & 29.011 & 0.000 \\
\hline $\mathrm{FC}$ & $\mathrm{Ta}$ & Sd & 72.510 & 14.850 & 0.000 & Wfm & $\mathrm{Cp}$ & -70.737 & 24.254 & 0.021 \\
\hline G & & & & & & Wfm & Wf & 48.331 & 16.473 & 0.020 \\
\hline
\end{tabular}

Note: NL, natural landscape; HL, human landscape; F, forest; W, waterscape; IS, ice and snow; BL, bare land; M, meadow; WT, weather; $\mathrm{H}$, heritage; CF, customs and festivals; A, architecture; FC, folk culture; G, gastronomy; Sd, Self-driving; Ta, Travel agency; Pt, Public transportation; Ind, Individual; Wf, With friends; Wfm, With family members; Cp, Couples. 2. We keep only significant multiple comparison results in the table.

\section{References}

1. Tian, J.; Ming, Q. Hotspots, progress and enlightenments of foreign mountain tourism research. World Reg. Stud. 2020, 29, 1071-1081. [CrossRef]

2. Chen, X.; Qin, J.; Li, X.; Shi, X. Study on Characteristic Development Strategies of Mountain Tourism in High Mountain Canyon Area of Hengduan Mountains in Sichuan-Exploring the Development Path of Mountain Tourism in Western China. Econ. Ggography 2012, 32, 143-148. [CrossRef]

3. Delitheou, V.; Alexiou, S. Challenges of Tourism Sustainability in Greek Mountain Regions in Decline. AJHSSR 2021, 5, 448-458. Available online: https:/ / www.researchgate.net/publication/350889823 (accessed on 3 November 2021). 
4. Paunović, I.; Jovanović, V. Implementation of Sustainable Tourism in the German Alps: A Case Study. Sustainability 2017, 9, 226. [CrossRef]

5. Rita, P.; Brochado, A.; Dimova, L. Millennials' Travel Motivations and Desired Activities within Destinations: A Comparative Study of the US and the UK. Curr. Issues Tour. 2019, 22, 2034-2050. [CrossRef]

6. Denning, A. From sublime landscapes to white gold: How skiing transformed the Alps after 1930. Environ. Hist. 2014, 19, 78-108. [CrossRef]

7. Giachino, C.; Truant, E.; Bonadonna, A. Mountain Tourism and Motivation: Millennial Students' Seasonal Preferences. Curr. Issues Tour. 2019, 23, 2461-2475. [CrossRef]

8. Silkes, C.A. Farmers' Markets: A Case for Culinary Tourism. J. Culin. Sci. Technol. 2012, 10, 326-336. [CrossRef]

9. Kotler, P.; Bowen, J.; Makens, J.; Baloglu, S. Marketing for Hospitality and Tourism, 7th ed.; Global Edition; Pearson: London, UK, 2017; p. 527.

10. Bond, N.; Falk, J. Tourism and identity-related motivations: Why am I here (and not there)? Int. J. Tour. Res. 2012, 15, 430-442. [CrossRef]

11. Falk, J. Identity and the art museum visitor. J. Art Educ. 2018, 34, 25-34. [CrossRef]

12. Cohen, S. Chasing a myth? Searching for 'self' through lifestyle travel. Tour. Stud. 2010, 10, 117-133. [CrossRef]

13. Michael, N.; Nyadzayo, M.W.; Michael, I.; Balasubramanian, S. Differential roles of push and pull factors on escape for travel: Personal and social identity perspectives. Int. J. Tour. Res. 2020, 22, 464-478. [CrossRef]

14. Foot, D.K.; Stoffman, D. Boom, Bust and Echo 2000: Profiting from the Demographic Shift in the New Millennium; Macfarlane, Walter \& Ross: Toronto, ON, Canada, 1998.

15. Nowak, L.; Thach, L.; Olsen, J.E. Wowing the Millennials: Creating Brand Equity in the Wine Industry. J. Prod. Brand Manag. 2006, 15, 316-323. [CrossRef]

16. Benckendorff, P.; Moscardo, G.; Pendergast, D. Generation Y and travel. In Tourism and Generation Y; Benckendorff, P., Moscardo, G., Pendergast, D., Eds.; CABI: Oxfordshire, UK, 2010; pp. 16-26.

17. Bernardi, M. Millennials, Sharing Economy and Tourism: The Case of Seoul. J. Tour. Futures 2018, 4, 43-56. [CrossRef]

18. Bonadonna, A.; Giachino, C.; Truant, E. Sustainability and Mountain Tourism: The Millennial's Perspective. Sustainability 2017, 9, 1219. [CrossRef]

19. Buckley, R. Sustainability issues in mountain tourism. In Sustainable Mountain Communities; Taylor, L., Ryall, A., Eds.; The Banff Centre: Banff, CAN, 2003; pp. 169-174.

20. Higham, J.; Thompson-Carr, A.; Musa, G. Activity, People and Place. In Mountaineering Tourism; Musa, G., Higham, J., ThompsonCarr, A., Eds.; Routledge: New York, NY, USA, 2015; pp. 1-15. [CrossRef]

21. Cavagnaro, E.; Staffieri, S. A Study of Students' Travellers Values and Needs in Order to Establish Futures Patterns and Insights. J. Tour. Futures 2015, 1, 94-107. [CrossRef]

22. Hopkins, D. Destabilising Automobility? The Emergent Mobilities of Generation Y. Ambio 2017, 46, 371-383. [CrossRef] [PubMed]

23. Miller, D.; Merrilees, B.; Coghlan, A. Sustainable Urban Tourism: Understanding and Developing Visitor pro-Environmental Behaviors. J. Sustain. Tour. 2015, 23, 26-46. [CrossRef]

24. Olsen, J.E.; Thach, L.; Nowak, L. Wine for My Generation: Exploring How Us Wine Consumers Are Socialized to Wine. J. Wine Res. 2007, 18, 1-18. [CrossRef]

25. Schoolman, E.D.; Shriberg, M.; Schwimmer, S.; Tysman, M. Green Cities and Ivory Towers: How Do Higher Education Sustainability Initiatives Shape Millennials' Consumption Practices? J. Environ. Stud. Sci. 2016, 6, 490-502. [CrossRef]

26. Tieskens, K.F.; Van Zanten, B.T.; Schulp, C.J.E.; Verburg, P.H. Aesthetic appreciation of the cultural landscape through social media: An analysis of revealed preference in the dutch river landscape. Landsc. Urban Plan. 2018, 117, 128-137. [CrossRef]

27. Oteros-Rozas, E.; Martín-López, B.; Fagerholm, N.; Bieling, C.; Plieninger, T. Using Social Media Photos to Explore the Relation between Cultural Ecosystem Services and Landscape Features across Five European Sites. Ecol. Indic. 2018, 94, 74-86. [CrossRef]

28. Kiatkawsin, K.; Han, H. Young Travelers' Intention to Behave pro-Environmentally: Merging the Value-Belief-Norm Theory and the Expectancy Theory. Tour. Manag. 2017, 59, 76-88. [CrossRef]

29. Rahman, O.; Fung, B.C.M.; Chen, Z. Young Chinese Consumers' Choice between Product-Related and Sustainable Cues-the Effects of Gender Differences and Consumer Innovativeness. Sustainability 2020, 12, 3818. [CrossRef]

30. Folmer, A.; Tengxiage, A.; Kadijk, H.; Wright, A.J. Exploring Chinese Millennials' Experiential and Transformative Travel: A Case Study of Mountain Bikers in Tibet. J. Tour. Futures 2019, 5, 142-156. [CrossRef]

31. Xiang, Z.; Gretzel, U. Role of Social Media in Online Travel Information Search. Tour. Manag. 2010, 31, 179-188. [CrossRef]

32. Sharmin, F.; Sultan, M.T.; Badulescu, A.; Bac, D.P.; Li, B. Millennial Tourists' Environmentally Sustainable Behavior towards a Natural Protected Area: An Integrative Framework. Sustainability 2020, 12, 8545. [CrossRef]

33. Oliveira, T.; Araujo, B.; Tam, C. Why Do People Share Their Travel Experiences on Social Media? Tour. Manag. 2020, 78, 104041. [CrossRef]

34. Zhang, Y.; Qiu, J.; Shao, L.; Cui, J.; Meng, X. The structure of pull motivations of rural tourism and the segmentation of rural tourists. J. Arid. Land Resour. Environ. 2014, 28, 191-196. [CrossRef]

35. Pettebone, D.; Newman, P.; Lawson, S.R.; Hunt, L.; Monz, C.; Zwiefka, J. Estimating Visitors' Travel Mode Choices along the Bear Lake Road in Rocky Mountain National Park. J. Transp. Geogr. 2011, 19, 1210-1221. [CrossRef] 
36. Chen, Y.Y.; Cheng, A.J.; Hsu, W.H. Travel recommendation by mining people attributes and travel group types from communitycontributed photos. IEEE Trans. Multimed. 2013, 15, 1283-1295. [CrossRef]

37. Ana, M.-I.; Istudor, L.-G. The Role of Social Media and User-Generated-Content in Millennials' Travel Behavior. Manag. Dyn. Knowl. Econ. 2019, 7, 87-104. [CrossRef]

38. Erdeji, I.; Dragin, A. Is Cruising along European Rivers Primarily Intended for Seniors and Workers from Eastern Europe? Geogr Pannonica 2017, 21, 115-123. [CrossRef]

39. Fall, L.T.; Lubbers, C.A. Promoting America: How Do College-Age Millennial Travelers Perceive Terms for Branding the USA? In Global Place Branding Campaigns across Cities, Regions, and Nations; IGI Global: Hershey, PA, USA, 2016; pp. 270-287. [CrossRef]

40. Loda, M.D.; Coleman, B.C.; Backman, K.F. Walking in Memphis: Testing One DMO's Marketing Strategy to Millennials. J. Travel Res. 2010, 49, 46-55. [CrossRef]

41. Casalegno, S.; Inger, R.; Desilvey, C.; Gaston, K.J. Spatial covariance between aesthetic value \& other ecosystem services. PLoS ONE 2013, 8, e68437. [CrossRef]

42. Wood, S.A.; Guerry, A.D.; Silver, J.M.; Lacayo, M. Using Social Media to Quantify Nature-Based Tourism and Recreation. Sci. Rep. 2013, 3, 2976. [CrossRef]

43. Schlieder, C.; Matyas, C. Photographing a city: An analysis of place concepts based on spatial choices. Spat. Cogn. Comput. 2009, 9, 221-228. [CrossRef]

44. Van Zanten, B.T.; Van Berkel, D.B.; Meentemeyer, R.K.; Smith, J.W.; Tieskens, K.F.; Verburg, P.H. Continental-Scale Quantification of Landscape Values Using Social Media Data. Proc. Natl. Acad. Sci. USA 2016, 113, 12974-12979. [CrossRef] [PubMed]

45. Richards, D.R.; Friess, D.A. A Rapid Indicator of Cultural Ecosystem Service Usage at a Fine Spatial Scale: Content Analysis of Social Media Photographs. Ecol. Indic. 2015, 53, 187-195. [CrossRef]

46. Richards, D.R.; Tunçer, B. Using image recognition to automate assessment of cultural ecosystem services from social media photographs. Ecosyst. Serv. 2017, 31, 318-325. [CrossRef]

47. Tenerelli, P.; Demšar, U.; Luque, S. Crowdsourcing Indicators for Cultural Ecosystem Services: A Geographically Weighted Approach for Mountain Landscapes. Ecol. Indic. 2016, 64, 237-248. [CrossRef]

48. Hausmann, A.; Toivonen, T.; Slotow, R.; Tenkanen, H.; Moilanen, A.; Heikinheimo, V.; Di Minin, E. Social media data can be used to understand tourists' preferences for nature-based experiences in protected areas. Conserv. Lett. 2018, 11, e12343. [CrossRef]

49. Kirilenko, A.P.; Stepchenkova, S.O. Sochi 2014 Olympics on Twitter: Perspectives of Hosts and Guests. Tour. Manag. 2017, 63, 54-65. [CrossRef]

50. Mayer-Schönberger, V.; Cukier, K. Big data: A revolution that will transform how we live, work, and think. J. Epid. 2014, 179, 1143-1144.

51. Eagle, N.; Pentland, A.; Lazer, D. Inferring Friendship Network Structure by Using Mobile Phone Data. Proc. Natl. Acad. Sci. USA 2009, 106, 15274-15278. [CrossRef]

52. Krippendorff, K. Content Analysis: An Introduction to its Methodology. by Klaus Krippendorff. J. Am. Stat. Assoc. 1984, 79, 240. [CrossRef]

53. Li, B. Description of communication content characteristics test of communication research hypothesis content analysis method. Contemp. Commun. 1999, 6, 39-40.

54. Li, B.; Dong, S.; Xue, M. Ecotourism model and benefit analysis in the marginal areas of ethnic minorities in Western Sichuan. Rural. Econ. 2008, 3, 51-54.

55. Zhang, J.; Zhang, Y. Trade-Offs between Sustainable Tourism Development Goals: An Analysis of Tibet (China). Sustain. Dev 2019, 27, 109-117. [CrossRef]

56. Dong, S.; Li, B.; Jin, X. Research on Eco-tourism Development Patterns in the Ethnic Regions of Western Sichuan Province under the Comprehensive Tourism Strategy. China Popul. Resour. Environ. 2009, 19, 117-122.

57. Konu, H.; Laukkanen, T. Predictors of Tourists' Wellbeing Holiday Intentions in Finland. J. Hosp. Tour. Manag. 2010, 17, 144-149. [CrossRef]

58. Mohammed Alsawafi, A. Sport Tourism: An Exploration of the Travel Motivations and Constraints of Omani Tourists. Anatolia 2017, 28, 239-249. [CrossRef]

59. Hanmei, C. Summarization of Human Tourism Resources in Garze Tibetan Autonomous Prefecture. J. Sichuan Univ. Natl. 2013, 22, 48-54. [CrossRef]

60. Shi, Q.; Wang, Z.; He, L.; Shi, Q.; Anayeti, A.; Liu, M.; Change, S. Landscape Classification System Based on Climate, Landform, Ecosystem: A Case Study of Xinjiang Area. Shengtai Xuebao/Acta Ecol. Sin. 2014, 34, 3359-3367. [CrossRef]

61. Kimbrough, A.M.; Guadagno, R.E.; Muscanell, N.L.; Dill, J. Gender Differences in Mediated Communication: Women Connect More than Do Men. Comput. Hum. Behav. 2013, 29, 896-900. [CrossRef]

62. Krueger, R.; Rashidi, T.H.; Vij, A. X vs. Y: An Analysis of Intergenerational Differences in Transport Mode Use among Young Adults. Transportation 2020, 47, 2203-2231. [CrossRef]

63. Teles da Mota, V.; Pickering, C. Using Social Media to Assess Nature-Based Tourism: Current Research and Future Trends. J. Outdoor Recreat. Tour. 2020, 30, 100295. [CrossRef]

64. Xu, F.; Morgan, M.; Song, P. Students' Travel Behavior: A Cross-Cultural Comparison of UK and China. Int. J. Tour. Res. 2009, 11, 255-268. [CrossRef] 
65. Hargittai, E.; Litt, E. The tweet smell of celebrity success: Explaining variation in Twitter adoption among a diverse group of young adults. New Media Soc. 2011, 13, 824-842. [CrossRef]

66. Yang, L. Cultural Tourism in an Ethnic Theme Park: Tourists' Views. J. Tour. Cult. Chang. 2011, 9, 320-340. [CrossRef]

67. Yang, Y.; Liu, Z.H.; Qi, Q. Domestic Tourism Demand of Urban and Rural Residents in China: Does Relative Income Matter? Tour. Manag. 2014, 40, 193-202. [CrossRef]

68. Chen, Y.; Parkins, J.R.; Sherren, K. Using Geo-Tagged Instagram Posts to Reveal Landscape Values around Current and Proposed Hydroelectric Dams and Their Reservoirs. Landsc. Urban Plan. 2018, 170, 283-292. [CrossRef]

69. Luo, Y.; Deng, J. The New Environmental Paradigm and Nature-Based Tourism Motivation. J. Travel Res. 2008, 46, 392-402. [CrossRef] 